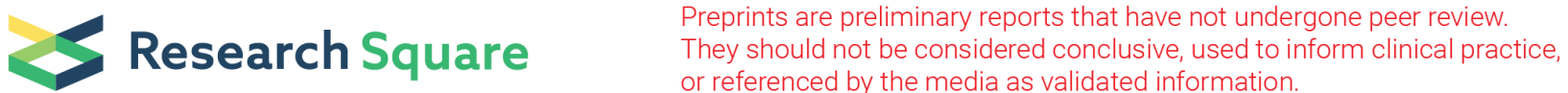 Effects of Air Pollution on COVID-19 and Public Health
}

Mario Coccia ( $\square$ mario.coccia@cnr.it)

National Research Council of Italy

\section{Research Article}

Keywords: Air pollution, Public Health, Particulate matter, Density of population, COVID-19, Coronavirus disease, Coronavirus infection, Viral pneumonia, SARS-CoV-2, Sustainable growth, Environmental Science

Posted Date: August 4th, 2020

DOl: https://doi.org/10.21203/rs.3.rs-41354/v1

License: (c) (i) This work is licensed under a Creative Commons Attribution 4.0 International License. Read Full License 


\title{
EFFECTS OF AIR POLLUTION ON COVID-19 AND PUBLIC HEALTH
}

\author{
Mario Coccia \\ CNR -- NATIONAL RESEARCH COUNCIL OF ITALY \\ Research Institute on Sustainable Economic Growth \\ Collegio Carlo Alberto, Via Real Collegio, 30-10024 Moncalieri (Torino, Italy)
}

\begin{abstract}
The pandemic of coronavirus disease 2019 (COVID-19), generate by a novel virus SARS-CoV-2, is rapidly spreading all over the world, generating a high number of deaths. One of the current questions in the field of environmental science is to explain the relationships determining the diffusion of COVID-19 in specific regions of countries. The research here focuses on case study of Italy, one of the countries in the World to experience a rapid increase in confirmed cases and deaths. Results suggest that diffusion of COVID-19 is very high in cities with high air pollution generating severe negative effects on public health $\mathrm{o}$. In particular, results reveal that, among Italian provincial capitals, the number of infected people was higher in cities with more than 100 days per year exceeding limits set for $\mathrm{PM}_{10}$ or ozone, cities located in hinterland zones (i.e. away from the coast), cities having a low average intensity of wind speed and cities with a lower temperature. In hinterland cities (mostly those bordering large urban conurbations) with a high number of days exceeding $\mathrm{PM}_{10}$ and ozone limits, coupled with low wind speed (atmospheric stability), the average number of infected people in April 2020 more than tripled those that had less than 100 days of excessive air pollution. In fact, results show that more than $75 \%$ of infected individuals and about $81 \%$ of deaths in Italy of COVID-19 are in regions with high air pollution. This study must conclude that a long-run strategy to constrain future epidemics similar to the COVID-19, reducing the negative impact on public health has also to be designed in terms of environmental and sustainability policies and not only in terms of efficient approaches in medicine.
\end{abstract}

Keywords: Air pollution, Public Health, Particulate matter, Density of population, COVID-19, Coronavirus disease, Coronavirus infection, Viral pneumonia, SARS-CoV-2, Sustainable growth, Environmental Science. 


\section{INTRODUCTION}

Coronavirus disease 2019 (COVID-19) is viral infection that generates a severe acute respiratory syndrome with cardiovascular and respiratory disorders and is the cause of death of many individuals (Gattinoni et al., 2020; Ogen, 2020; Sterpetti, 2020; Wang et al., 2020). COVID-19 has created a world emergence and is threatening world public health security, creating socioeconomic issues (Wang and Su, 2020; cf., Coccia, 2016). The pandemic of COVID-19 is creating public health issues worldwide but also uncertainty in markets and turbulence in socioeconomic systems of nations (Sohrabi et al., 2020; Wang and Su, 2020). Economic studies point out that the global economy may have an economic recession of about by $2.2 \%$ and many countries may contract by more than $8 \%$ of real GDP growth $\%$ in 2020 (EIU, 2020; cf., Coccia, 2017).

In this context of emergence of COVID-19, the main goal of this study is to explain the relation between air pollution and the diffusion of COVID-19 to suggest environmental policies to cope with future epidemics and infections in society. This study revels new findings of how geo-environmental factors may have accelerated the spread of COVID-19 in Italy, one of the countries in the World to experience a rapid increase in confirmed cases of infection and deaths (Coccia, 2020). In particular, this study explains how COVID-19 transmitted so rapidly in northern Italy, analyzing the underlying relationships between infected people and environmental, demographic, and geographical factors that influenced its spread. This study analyses data on COVID-19 cases alongside environmental data. It shows that cities with little wind, high humidity and frequently high levels of air pollution — exceeding safe levels of ozone or particulate matter — had higher numbers of COVID-19 related infected individuals and deaths.

The study concludes that a proactive strategy to help cope with future epidemics similar to COVID-19 should concentrate on reducing levels of air pollution in hinterland and polluted cities. Therefore, countries have to design a sustainable policy that takes into account socioeconomic and environmental factors of affected regions having high air pollution, not only factors related to biology, medicine and the health sector. 


\section{DATA AND STUDY DESIGN}

\subsection{Data and their sources}

The study here focuses on case study of Italy, one of the countries in the World to experience a rapid increase in confirmed cases of COVID-19 and deaths. In particular, the sample is based on 55 Italian cities that are provincial capitals. Sources of data are Ministero della Salute (2020) for data of infected people and deaths, Regional Agencies for Environmental Protection in Italy for data of air pollution (Legambiente, 2019), meteorological stations of Italian province capitals for climatological information (il Meteo, 2020), the Italian National Institute of Statistics for data on the density of population of cities under study (ISTAT, 2020).

\subsection{Measures}

- Air Pollution. Total days exceeding the limits set for $\mathrm{PM}_{10}$ (particulate matter 10 micrometers or less in diameter) or for ozone in 2018. Air pollution is a main factor that affects health of population and environment in the long run. The study uses 2018 as the baseline year for air pollution data to separate out the effects of COVID-19.

- Diffusion of COVID-19. Number of infected individuals in March and April 2020 per Italian province capitals and number of deaths in regions.

- Weather information. Average temperature in ${ }^{\circ} \mathrm{C}$, wind speed $\mathrm{km} / \mathrm{h}$ in February-April 2020

- Interpersonal contact rates. Population density of cities (individual / $\mathrm{km}^{2}$ ) in 2019

\subsection{Data analysis and procedure}

Firstly, data are analyzed with descriptive statistics, using a comparative approach, based on mean and std. deviation considering groups of cities using the following taxonomic criteria (cf., Coccia and Benati, 2018):

- Airpollution

- Cities with high Air pollution (> 100 days per year exceeding the limits set for $\mathrm{PM}_{10}$ or for ozone per year)

- Cities with low Air pollution ( $\leq 100$ days per year exceeding the limits set for $\mathrm{PM}_{10}$ or for ozone) 
- Density of population

- Cities with high density of population, $>1000$ inhabitant $/ \mathrm{km}^{2}$

- Cities with low density of population, $\leq 1000$ inhabitant $/ \mathrm{km}^{2}$

Secondly, bivariate and partial correlation verifies relationships (or associations) between variables understudy.

Thirdly, simple and multiple regression analyses. In particular, the specification of linear relationship is based on $\log$ $\log$ models of simple regression:

$\log y_{t}=\alpha+\beta \log x_{t-1}+u$

$y=$ number of infected individuals in cities

$x=$ a measure of air pollution (total days exceeding the limits set for $\mathrm{PM}_{10}$ or ozone in cities)

The equation [1] is also applied considering cities according to level of air pollution and density of population as mentioned above. This study extends the analysis with a multiple regression based on linear relationship of a $\log -\log$ model as follows:

$\log y_{t}=\alpha+\beta_{1} \log x_{1, t-1}+\beta_{2} \log x_{2, t-1}+u$

$y=$ number of infected individuals in cities

$x_{1}=$ a measure of air pollution, $\quad x_{2}=$ population density of cities, inhabitants $/ \mathrm{km}^{2}$

Ordinary Least Squares (OLS) method is applied for estimating the unknown parameters of linear models [1-2]. In addition, effects of COVID-19 on public health of regions with bigh or low air pollution, considering data of cities within regions, is performed considering data of total infected and total deaths. In particular, as not all the confirmed cases and deaths in regions with high and low air pollution have the same importance because of different level of total population in these groups of regions, a weighted percentage is calculated in which infected individuals and total deaths are weighted with population of regions with high and low air pollution to provide a critical measure of spatial effect of Coronavirus infection and mortality on public health. Statistical analyses are performed with the Statistics Software SPSS ${ }^{\circledR}$ version 24. 


\section{RESULTS}

Table 1. Descriptive statistics of Italian provincial capitals according to level of air pollution

\begin{tabular}{|c|c|c|c|c|c|c|c|}
\hline & $\begin{array}{c}\text { Days } \\
\text { exceeding } \\
\text { limits set } \\
\text { for } \mathrm{PM}_{10} \\
\text { or ozone } \\
2018\end{array}$ & $\begin{array}{c}\text { Infected } \\
\text { Individuals } \\
17^{\text {th }} \text { March } \\
2020\end{array}$ & $\begin{array}{l}\text { Infected } \\
\text { Individuals } \\
7^{\text {th }} \text { April } \\
2020\end{array}$ & $\begin{array}{c}\text { Infected } \\
\text { Individuals } \\
27^{\text {th }} \text { April } \\
2020\end{array}$ & $\begin{array}{c}\text { Density } \\
\text { inhabitants } / \mathrm{km}^{2} \\
2019\end{array}$ & $\begin{array}{c}\text { Temp }{ }^{\circ} \mathrm{C} \\
\text { Feb-Mar } \\
2020\end{array}$ & $\begin{array}{l}\text { Wind } \\
\mathrm{km} / \mathrm{h} \\
\text { Feb-Mar } \\
2020\end{array}$ \\
\hline \multicolumn{8}{|c|}{$\begin{array}{c}\text { Cities with HIGH Air pollution } \\
\qquad \mathrm{N}=20\end{array}$} \\
\hline Mean & 125.25 & 881.70 & 3650.00 & 4838.05 & 1981.40 & 9.19 & 7.67 \\
\hline Std. Deviation & 13.40 & 1010.97 & 3238.82 & 4549.41 & 1988.67 & 1.46 & 2.86 \\
\hline \multicolumn{8}{|c|}{$\begin{array}{l}\text { Cities with LOW Air pollution } \\
\qquad N=35\end{array}$} \\
\hline Mean & 48.77 & 184.11 & 1014.63 & 1637.21 & 1151.57 & 9.49 & 9.28 \\
\hline Std. Deviation & 21.37 & 202.76 & 768.91 & 1292.26 & 1466.28 & 2.62 & 4.15 \\
\hline
\end{tabular}

Table 1 shows that among Italian provincial capitals, the number of infected people is higher in cities with $>100$ days per year exceeding limits set for $\mathrm{PM}_{10}$ or ozone, i.e., cities located in zones of polluting industrialization, cities having a low average intensity of wind speed and cities with a lower temperature.

Table 2. Descriptive statistics of Italian provincial capitals according to population density

\begin{tabular}{|c|c|c|c|c|c|c|c|}
\hline & $\begin{array}{c}\text { Days } \\
\text { exceeding } \\
\text { limits set } \\
\text { for } \mathrm{PM}_{10} \\
\text { or ozone } \\
2018\end{array}$ & $\begin{array}{c}\text { Infected } \\
\text { Individuals } \\
17^{\text {th }} \text { March } \\
2020\end{array}$ & $\begin{array}{c}\text { Infected } \\
\text { Individuals } \\
7^{\text {th }} \text { April } \\
2020\end{array}$ & $\begin{array}{c}\text { Infected } \\
\text { Individuals } \\
27^{\text {th }} \text { April } \\
2020\end{array}$ & $\begin{array}{c}\text { Density } \\
\text { inhabitants } / \mathrm{km}^{2} \\
2019\end{array}$ & $\begin{array}{c}\text { Temp }{ }^{\circ} \mathrm{C} \\
\text { Feb-Mar } \\
2020\end{array}$ & $\begin{array}{l}\text { Wind } \\
\mathrm{km} / \mathrm{h} \\
\text { Feb-Mar } \\
2020\end{array}$ \\
\hline \multicolumn{8}{|c|}{$\begin{array}{l}\text { Cities with HIGH Density } \\
\qquad N=25\end{array}$} \\
\hline Mean & 91.24 & 665.08 & 2967.44 & 4195.42 & 2584.40 & 8.63 & 7.99 \\
\hline Std. Deviation & 40.24 & 919.70 & 3092.46 & 4333.91 & 2000.63 & 2.40 & 2.79 \\
\hline \multicolumn{8}{|c|}{$\begin{array}{c}\text { Cities with LOW density } \\
N=30\end{array}$} \\
\hline Mean & 64.37 & 248.37 & 1144.20 & 1727.55 & 510.77 & 10.01 & 9.28 \\
\hline Std. Deviation & 39.25 & 386.95 & 1065.99 & 1491.47 & 282.11 & 1.95 & 4.41 \\
\hline
\end{tabular}


The results also suggest that, among Italian provincial capitals, the number of infected people of COVID-19 was higher in cities with average density of people $/ \mathrm{km} 2$ (mostly those bordering large urban conurbations, such as Brescia, Bergamo, Cremona clos to Milan in Lombardia region of Italy) that are cities located in hinterland zones with a high number of days exceeding $\mathrm{PM}_{10}$ and ozone limits (i.e., Air Pollution), coupled with low wind speed, and a lower temperature.

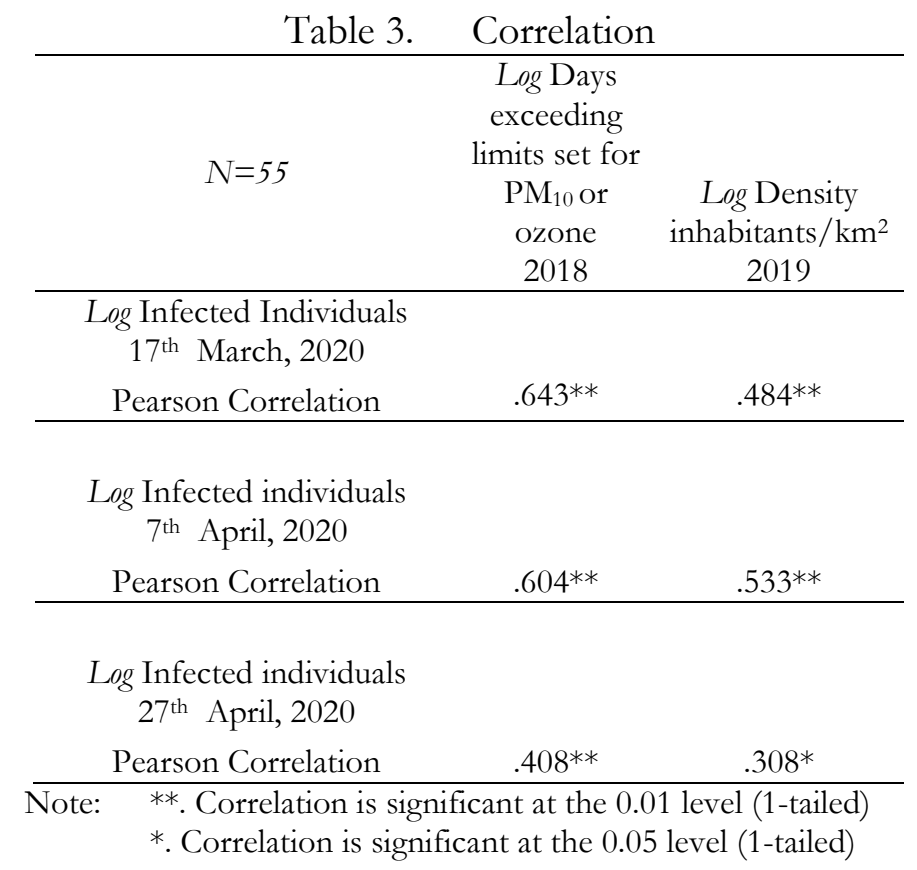

Table 3 shows a very high positive correlation between air pollution and infected individuals. The reduction of intensity of the association over time is due to quarantine and lockdown in Italy from March to May 2020 that have drastically reduced air pollution in cities that studies suggest to be one of the drivers of the diffusion of COVID-19 (cf., Contini and Costabile, 2020; Conticini et al., 2020; Fattorini and Regoli, 2020). Wang and Su (2020) also argue that quarantine and lockdown can protect the public from COVID-19 generating a positive effect on the environment and public health in the long run. 
Table 4. Partial Correlation between air pollution and infected individuals, controlling climatological factors

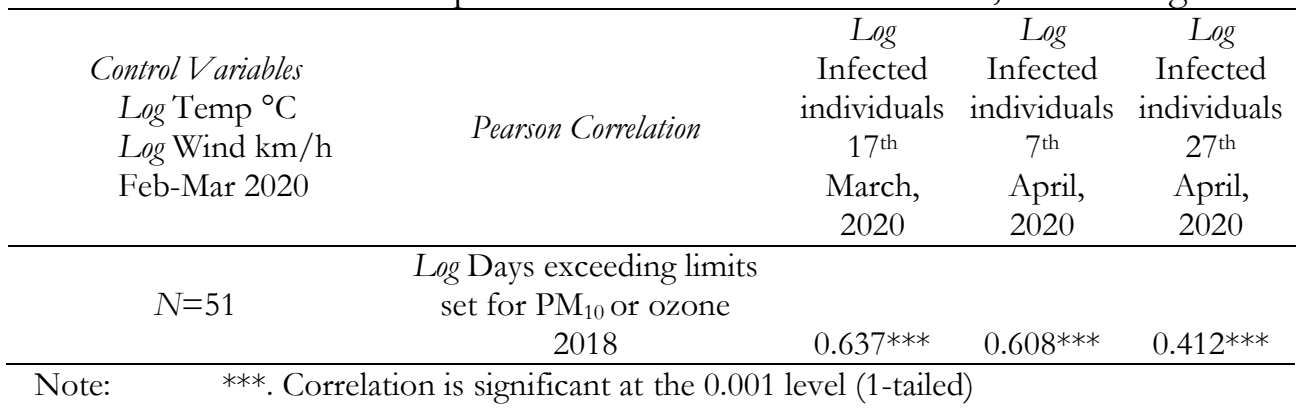

Table 4 confirms the high partial coefficient of correlation between air pollution and infected individuals, controlling climatological factors of cities. Partial correlation in table 5 suggests that, controlling density of population, the association between number of infected people and air pollution has a very high coefficient of partial correlation. In general, these results suggest that cities with frequently high levels of air pollution — exceeding safe levels of ozone or particulate matter — had higher numbers of COVID-19 related infected individuals and deaths.

Table 5. Partial Correlation between air pollution and infected individuals, population density

\begin{tabular}{|c|c|c|c|c|}
\hline $\begin{array}{l}\text { Control Variables } \\
\text { Log Density } \\
\text { inhabitants } / \mathrm{km}^{2} \\
2019\end{array}$ & Pearson Correlation & $\begin{array}{c}\log \\
\text { Infected } \\
17 \text { March, } \\
2020\end{array}$ & $\begin{array}{c}\log \\
\text { Infected } \\
7 \text { April } \\
2020\end{array}$ & $\begin{array}{l}\log \\
\text { Infected } \\
27 \text { April, } \\
2020\end{array}$ \\
\hline & $\begin{array}{c}\text { Log Days exceeding limits } \\
\text { set for } \mathrm{PM}_{10} \text { or ozone } \\
2018\end{array}$ & $0.542^{* * *}$ & $0.479 * * *$ & $0.316^{*}$ \\
\hline
\end{tabular}

\begin{tabular}{ll}
\hline$* *$. Correlation is significant at the 0.001 level (1-tailed) \\
Note: Correlation is significant at the 0.01 level $(1$-tailed)
\end{tabular}


Table 6. Estimated relationships of the linear model of Infected individuals on Air Pollution and Interpersonal contacts

\begin{tabular}{|c|c|c|c|c|c|}
\hline & $\begin{array}{c}\text { Model } 1 \\
\text {-Air pollution } \\
\text {-Interpersonal contacts }\end{array}$ & & $\begin{array}{c}\text { Model } 2 \\
\text {-Air pollution } \\
\text {-Interpersonal contacts }\end{array}$ & & $\begin{array}{c}\text { Model } 3 \\
\text {-Air pollution } \\
\text {-Interpersonal contacts }\end{array}$ \\
\hline $\begin{array}{l}\log \text { infected } \\
17^{\text {th }} \text { March, } 2020\end{array}$ & & $\begin{array}{l}\log \text { infected } \\
7^{\text {th }} \text { April, } 2020 \\
\end{array}$ & & $\begin{array}{l}\text { log infected } \\
27^{\text {th }} \text { April, } 2020\end{array}$ & \\
\hline $\begin{array}{l}\text { Constant } \alpha \\
\text { (St. Err.) }\end{array}$ & $\begin{array}{l}-2.168 \\
(1.127)\end{array}$ & $\begin{array}{l}\text { Constant } \alpha \\
\text { (St. Err.) }\end{array}$ & $\begin{array}{l}1.538 \\
(.854)\end{array}$ & $\begin{array}{l}\text { Constant } \alpha \\
\text { (St. Err.) }\end{array}$ & $\begin{array}{l}1.407 \\
(1.701)\end{array}$ \\
\hline $\begin{array}{l}\log \text { Days exceeding } \\
\text { limits set for } \mathrm{PM}_{10} \\
\text { in } 2018\end{array}$ & & & & & \\
\hline $\begin{array}{l}\text { Coefficient } \beta 1 \\
\text { (St. Err.) }\end{array}$ & $\begin{array}{l}1.266^{* * *} \\
(.272)\end{array}$ & $\begin{array}{l}\text { Coefficient } \beta 1 \\
\text { (St. Err.) }\end{array}$ & $\begin{array}{l}.813^{* * *} \\
(.206)\end{array}$ & $\begin{array}{l}\text { Coefficient } \beta 1 \\
\text { (St. Err.) }\end{array}$ & $\begin{array}{l}.987 * \\
(.411)\end{array}$ \\
\hline $\begin{array}{l}\log \text { Density } \\
\text { inhabitants } \\
/ \mathrm{km}^{2} \text { in } 2019\end{array}$ & & & & & \\
\hline $\begin{array}{l}\text { Coefficient } \beta 2 \\
\text { (St. Err.) }\end{array}$ & $\begin{array}{l}.309 * \\
(.148)\end{array}$ & $\begin{array}{l}\text { Coefficient } \beta 2 \\
\text { (St. Err.) }\end{array}$ & $\begin{array}{l}.314^{* *} \\
(.112)\end{array}$ & $\begin{array}{l}\text { Coefficient } \beta 2 \\
\text { (St. Err.) }\end{array}$ & $\begin{array}{l}.244 \\
(.223)\end{array}$ \\
\hline$F$ & $22.059 * * * \mathrm{c}$ & & $21.130^{* * *} \mathrm{c}$ & $F$ & $5.916^{* *} \mathrm{c}$ \\
\hline$R^{2}$ & 0.459 & $R^{2}$ & .448 & $R^{2}$ & .185 \\
\hline $\begin{array}{l}* * * p \text {-value } \\
* * \quad p \text {-value } \\
* \quad p \text {-value } \\
\mathrm{c}=\text { predic }\end{array}$ & $\begin{array}{l}<0.01 \\
<0.01 \\
<0.05 \\
\text { ors: } \log \text { Days }\end{array}$ & 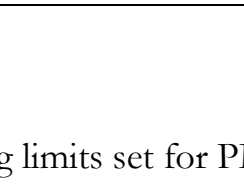 & 2018 year; $L$ & inhabitants & \\
\hline
\end{tabular}

Table 6 reveals that, in the period before air pollution reduced because of lockdown (Model 1), air pollution was a more important factor for COVID-19 transmission than human-to-human transmission. However, when air pollution decreased but human dynamics stayed the same under lockdown and quarantine (Model 3), transmission of COVID-19 by air pollution reduced in importance. This suggests that although COVID-19 transmits from human to human, the factor of air pollution can support a rapid diffusion transmission of COVID-19 in cities with little wind, high humidity and frequently high levels of air pollution. This effect can be due to that COVID-19, in the presence of high levels of air pollution, can remain viable in aerosols for hours (van Doremalen et al., 2020). 
These results are confirmed in table 7 that considers cities with LOW and HIGH air pollution: findings suggest that density of population explains the number of infected individuals, but the driving role of interpersonal contacts is stronger in cities with frequently high levels of air pollution. In particular, on $7^{\text {th }}$ April 2020, in the middle of COVID19 outbreak in Italy,

- in cities with low air pollution, an increase of $1 \%$ of the density of population, it increases the expected number of infected individuals by about $0.25 \%(P=.042)$

○ in cities with high air pollution, an increase of $1 \%$ of the density of population, it increases the expected number of infected individuals by about $85 \%(P<.001)$.

Figure 1 shows the regression lines confirming that diffusion of COVID-19 has a higher level and faster growth in cities with high level of air pollution (cf., Morawska and Cao, 2020). 
Table 7. Estimated relationship of Infected individuals on Population Density, considering the groups of cities with Low and High level of Air pollution

\begin{tabular}{|c|c|c|c|}
\hline & Cities with $L O W$ Air pollution & & Cities with HIGH Air pollution \\
\hline$\downarrow$ DEPENDENT VARIABLE & $\begin{array}{c}\text { Explanatory variable: } \\
\text { Log Density inhabitants } / \mathrm{km}^{2} \\
2019 \\
\end{array}$ & $\downarrow$ DEPENDENT VARIABLE & $\begin{array}{c}\text { Explanatory variable: } \\
\text { Log Density inhabitants } / \mathrm{km}^{2} \\
2019 \\
\end{array}$ \\
\hline $\begin{array}{l}\text { log infected } \\
17^{\text {th }} \text { March, } 2020\end{array}$ & & $\begin{array}{l}\text { log infected } \\
17^{\text {th }} \text { March, } 2020\end{array}$ & \\
\hline $\begin{array}{l}\text { Constant } \alpha \\
\text { (St. Err.) }\end{array}$ & $\begin{array}{l}2.346^{*} \\
(1.131)\end{array}$ & $\begin{array}{l}\text { Constant } \alpha \\
\text { (St. Err.) }\end{array}$ & $\begin{array}{l}.242 \\
(2.267)\end{array}$ \\
\hline $\begin{array}{l}\text { Coefficient } \beta 1 \\
\text { (St. Err.) }\end{array}$ & $\begin{array}{l}0.358^{*} \\
(0.172)\end{array}$ & $\begin{array}{l}\text { Coefficient } \beta 1 \\
\text { (St. Err.) }\end{array}$ & $\begin{array}{l}0.816^{* *} \\
(0.311)\end{array}$ \\
\hline $\begin{array}{l}\mathrm{R}^{2} \text { (St. Err. of Estimate) } \\
F\end{array}$ & $0.116(1.168)$ & $\mathrm{R}^{2}$ (St. Err. of Estimate) & $0.276(1.121)$ \\
\hline 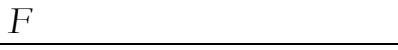 & $4.324 *$ & $F$ & $6.864^{* *}$ \\
\hline $\begin{array}{l}\text { log infected } \\
7^{\text {th }} \text { April, } 2020\end{array}$ & & $\begin{array}{l}\log \text { infected } \\
7^{\text {th }} \text { April, } 2020\end{array}$ & \\
\hline $\begin{array}{l}\text { Constant } \alpha \\
\text { (St. Err.) }\end{array}$ & $\begin{array}{l}4.976 \\
(.786)\end{array}$ & $\begin{array}{l}\text { Constant } \alpha \\
\text { (St. Err.) }\end{array}$ & $\begin{array}{l}1.670 \\
(1.491)\end{array}$ \\
\hline $\begin{array}{l}\text { Coefficient } \beta 1 \\
\text { (St. Err.) }\end{array}$ & $\begin{array}{l}.252^{*} \\
(.120)\end{array}$ & $\begin{array}{l}\text { Coefficient } \beta 1 \\
\text { (St. Err.) }\end{array}$ & $\begin{array}{l}.849 * * * \\
(.205)\end{array}$ \\
\hline $\mathrm{R}^{2}$ (St. Err. of Estimate) & .119 & $\mathrm{R}^{2}$ (St. Err. of Estimate) & .488 \\
\hline$F$ & $17.168^{* * *}$ & F & $4.457 *$ \\
\hline $\begin{array}{l}\text { log infected } \\
27^{\text {th }} \text { April, } 2020\end{array}$ & & $\begin{array}{l}\text { log infected } \\
27^{\text {th }} \text { April, } 2020\end{array}$ & \\
\hline $\begin{array}{l}\text { Constant } \alpha \\
\text { (St. Err.) }\end{array}$ & $\begin{array}{l}5.310^{* *} \\
(1.848)\end{array}$ & $\begin{array}{l}\text { Constant } \alpha \\
\text { (St. Err.) }\end{array}$ & $\begin{array}{l}3.189 * \\
(1.566)\end{array}$ \\
\hline $\begin{array}{l}\text { Coefficient } \beta 1 \\
\text { (St. Err.) }\end{array}$ & $\begin{array}{l}.203 \\
(0.281)\end{array}$ & $\begin{array}{l}\text { Coefficient } \beta 1 \\
\text { (St. Err.) }\end{array}$ & $\begin{array}{l}0.242^{* *} \\
(0.215)\end{array}$ \\
\hline $\mathrm{R}^{2}$ (St. Err. of Estimate) & $.016(1.909)$ & $\mathrm{R}^{2}$ (St. Err. of Estimate) & $0.357(.775)$ \\
\hline$F$ & .521 & F & $9.988^{* *}$ \\
\hline
\end{tabular}

Note: Explanatory variable: $\log$ Density inhabitants $/ \mathrm{km}^{2}$ in 2019; dependent variable $\log$ infected individuals

*** $\quad p$-value $<0.001$

$* * \quad \quad \quad p$-value $<0.01$

* $\quad p$-value $<0.05$ 


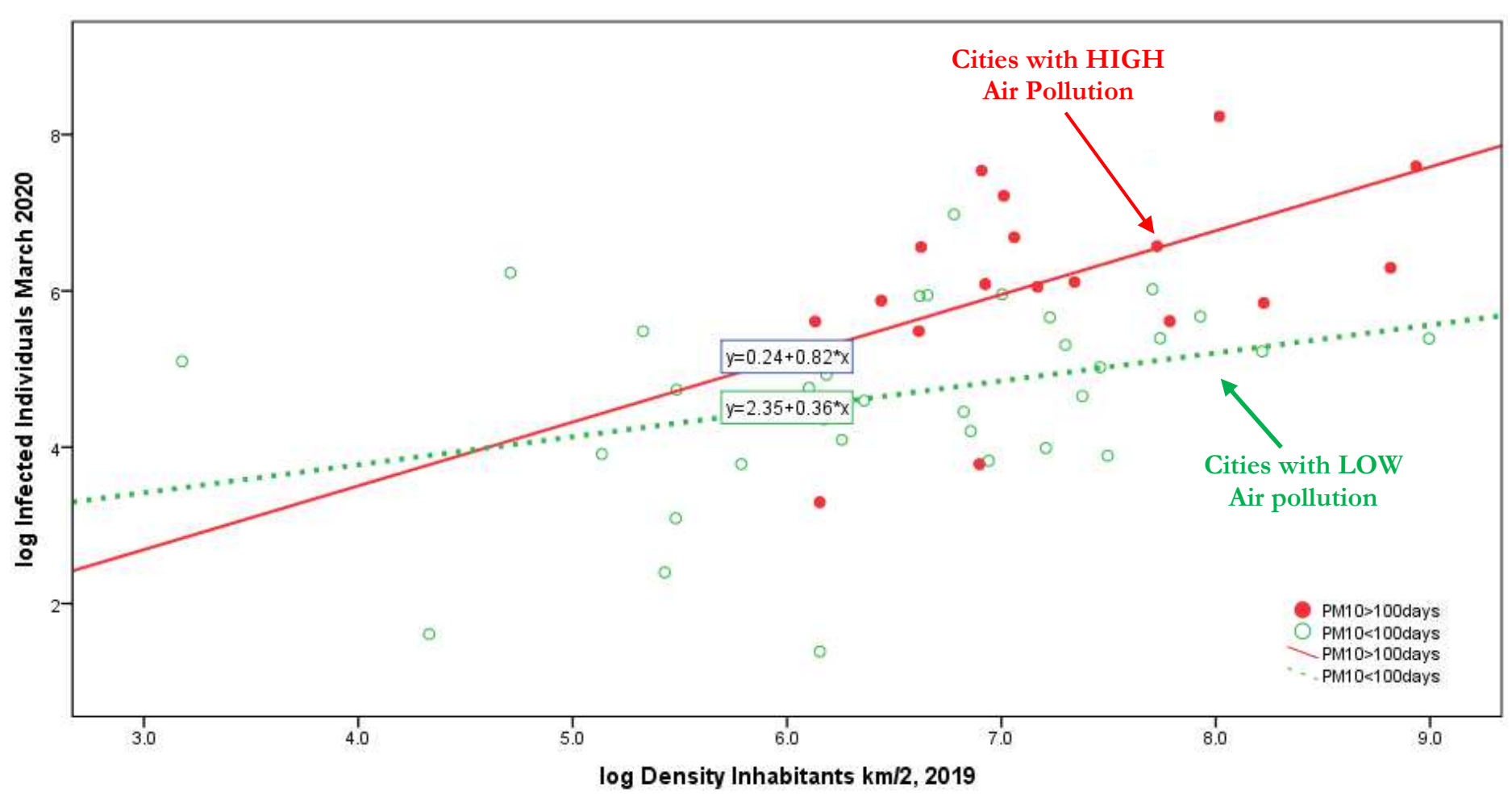

Figure 1: Regression line of Infected individuals on population density, considering cities with bigh or low Air pollution.

\section{DISCUSSION AND CONCLUSION}

What are the effects of air pollution on public health in the presence of COVID-19?

The main result of the study here, based on case study of COVID-19 outbreak in Italy, are that the diffusion of COVID-19 in North Italy has a high association with air pollution of cities generating main public health issues. In general, new findings are that geo-environmental factors may have accelerated the spread of COVID-19 in northern Italian cities, leading to a higher number of infected individuals and deaths. This study finds out that cities with little wind, high humidity and frequently high levels of air pollution — exceeding safe levels of ozone or particulate matter — had higher numbers of COVID-19 related infected individuals and deaths. The effects of air pollution on public health in Italy are summarized in the table 8 considering regions. 
Table 8. Effects of Air pollution on public health in the presence of COVID-19: Italy, May 2020

\begin{tabular}{|c|c|c|c|c|c|}
\hline $\begin{array}{l}\text { Public health effects of } \\
\text { COVID-19 }\end{array}$ & $\begin{array}{l}\text { Regions with HIGH } \\
\text { Air pollution } \\
>65 \text { Days exceeding } \\
\text { limits set for } \mathrm{PM}_{10} \text { or } \\
\text { ozone }\end{array}$ & $\%$ & $\begin{array}{l}\text { Regions with LOW } \\
\text { Air pollution } \\
\leq 65 \text { Days exceeding } \\
\text { limits set for } \mathrm{PM}_{10} \text { or } \\
\text { ozone }\end{array}$ & $\%$ & Total \\
\hline Total infected individuals & 166,445 & $74.47^{(1)}$ & 35,096 & $25.53^{(1)}$ & 201,541 \\
\hline Mean of infected people & $27,740.83$ & & $4,103.5$ & & \\
\hline Standard Deviation & $2,6387.33$ & & $5,182.099$ & & \\
\hline Total deaths & 24,621 & $81.08^{(1)}$ & 3,533 & $18.92^{(1)}$ & 28,154 \\
\hline Mean of deaths & $5,013.71$ & & 504.714 & & \\
\hline Standard Deviation & $2,783.77$ & & 340.12 & & \\
\hline Total population & $31,265,000$ & & $19,229,711$ & & \\
\hline
\end{tabular}

Note: regions with high/low air pollution are based on arithmetic mean of days exceeding limits set for $\mathrm{PM}_{10}$ or ozone of cities;

(1) This percentage is calculated considering infected individuals and total deaths weighted with population of these group of regions

Table 8 shows that about $74.50 \%$ of infected individuals and about $81 \%$ of total death in Italy because of COVID19 are in regions with high air pollution. In fact, studies argue that accumulated airborne pollutants induce that microorganisms might be attached to particulate matter, so in environments with heavy air pollution, highly toxic pollutants in $\mathrm{PM}_{2.5}$ and $\mathrm{PM}_{10}$ may inhibit microbial growth (Coccia, 2020; Frontera et al., 2020).

Hence, nowadays the fact that high levels of air pollution have a detrimental effect on public health and environment is now rarely contested. Zhu et al. (2020) point out that governments should pay attention to cities and regions with high concentrations of pollutants in the air (e.g., $\mathrm{PM}_{2.5}, \mathrm{PM}_{10}, \mathrm{NO}_{2}, \mathrm{O}_{3}$, etc.) because these regions may wide negative effects on public health from epidemics similar to COVID-19 and/or other infections. In particular, in order to prevent epidemics similar to COVID-19 and other infections, nations have to apply sustainable policies directed to 
reduce air pollution that amplifies the negative effects of airborne viral diseases, affecting public health of population (Coccia, 2018, 2019). To put it differently, regions have to apply long-run sustainable polices directed to reduce air pollution and support the production of renewable energy and cleaner production (Wang and Zhu, 2020). In addition, in cities with polluting industrialization, the environmental policy for a sustainable development has to consider the urban and regional climatology for improving urban ventilation that can dilute pollutants and heat, enhance the exchange of air and reduce air pollution on trans-regional level and likely threats of accelerated diffusion of viral infectivity in winter and fall seasons (Gu et al., 2020; Wang and Zhu, 2020). The reduction of air pollutants by sustainable policies can be a useful measure to control and reduce the impact of infections and generate significant environmental, health and economic benefits in society. In fact, Cui et al. (2020), based on a study in China, show that where reductions in ambient air pollution have avoided more than 2,300 premature deaths and more than 15,80 related morbidity cases in 2017 , with a total of about US $\$ 318$ million in economic benefits. In addition, these scholars argue that reduction of $\mathrm{PM}_{2.5}$ concentrations to $15 \mu \mathrm{g} / \mathrm{m}^{3}$ would result in reductions of $70 \%$ in total $\mathrm{PM}_{2.5}$-related non-accidental mortality and $95 \%$ in total $\mathrm{PM}_{2.5}$-related morbidity, with economic benefits of more than US\$1,289.5 million.

Overall, then, these findings provide valuable insight into geo-environmental factors that may accelerate the diffusion of COVID-19 and similar viral agents. The results here reveal that, among Italian provincial capitals, the number of infected people was higher in cities high level of air pollution, cities located in hinterland zones (mostly those bordering large urban conurbations), cities having a low average intensity of wind speed and cities with a lower temperature. The northern Italian region covered by the study, and in general regions with air pollution, should not exceed $\mathrm{PM}_{10}$ and ozone limits for more than fifty days each year, so that the accelerated transmission dynamics of viral infectivity are not triggered.

However, these conclusions are of course tentative. There is need for much more research to elucidate the underlying relationships between infected people and environmental, demographic, and geographical factors that influenced the spread of COVID-19. To conclude, the current pandemic of Coronavirus disease and future epidemics similar to 
COVID-19 cannot be solved only with research and practice of medicine, immunology, biochemistry and molecular biology but also with the development of appropriate instruments of environmental policy for a sustainable society.

\section{Declaration of competing interest}

The author declares that he has no known competing financial interests or personal relationships that could have appeared to influence the work reported in this paper. No funding was received for this study.

\section{REFERENCES}

Coccia M. 2016. The relation between price setting in markets and asymmetries of systems of measurement of goods, The Journal of Economic Asymmetries, vol. 14, part B, November, pp. 168-178, https://doi.org/10.1016/j.jeca.2016.06.001

Coccia M. 2017. Asymmetric paths of public debts and of general government deficits across countries within and outside the European monetary unification and economic policy of debt dissolution, The Journal of Economic Asymmetries, vol. 15, June, pp. 17-31, https://doi.org/10.1016/j.techfore.2010.02.003

Coccia M. 2018. Theorem of not independence of any technological innovation, Journal of Economics Bibliography, vol. 5, n. 1, pp. 29-35, http://dx.doi.org/10.1453/jeb.v5i1.1578

Coccia M. 2019. Why do nations produce science advances and new technology? Technology in society, vol. 59, November, 101124, pp. 1-9, https://doi.org/10.1016/j.techsoc.2019.03.007

Coccia M. 2020. Factors determining the diffusion of COVID-19 and suggested strategy to prevent future accelerated viral infectivity similar to COVID, Science of the Total Environment, volume, 729, Article Number: 138474, https://doi.org/10.1016/j.scitotenv.2020.138474

Coccia M., Benati I. 2018. Comparative Studies. Global Encyclopedia of Public Administration, Public Policy, and Governance -section Bureaucracy (edited by Ali Farazmand). Chapter No. 1197-1, pp. 1-7, https://doi.org/10.1007/978-3-319-31816-5_1197-1, Springer International Publishing AG, Cham.

Conticini E., Frediani B., Caro D. 2020. Can atmospheric pollution be considered a co-factor in extremely high level of SARS-CoV-2 lethality in Northern Italy? Environmental Pollution, Volume 261,114465, https://doi.org/10.1016/j.envpol.2020.114465.

Contini, D., Costabile, F. 2020. Does Air Pollution Influence COVID-19 Outbreaks? Atmosphere, 11, 377.

Cui L., Zhou J., Peng X., Ruan S., Zhang Y. 2020. Analyses of air pollution control measures and co-benefits in the heavily air-polluted Jinan city of China, 2013-2017.Sci Rep. 2020 Mar 25;10(1):5423. doi: 10.1038/s41598-020-624750 .

EIU, 2020a. Q2 Global Forecast 2020. The Economist Intelligence Unit, London.

Fattorini D., Regoli F. 2020. Role of the chronic air pollution levels in the Covid-19 outbreak risk in Italy, Environmental Pollution, Volume 264,2020,114732, https://doi.org/10.1016/j.envpol.2020.114732.

Frontera A., Claire Martin, Kostantinos Vlachos, Giovanni Sgubin, 2020. Regional air pollution persistence links to COVID-19 infection zoning, J Infect. 2020 Apr 10 doi: 10.1016/j.jinf.2020.03.045 
Gattinoni, L. et al. 2020. Covid-19 Does not Lead to a 'Typical' Acute Respiratory Distress Syndrome. Am J Respir Crit Care Med. (2020). https://www.atsjournals.org/doi/pdf/10.1164/rccm.202003-0817LE

Gu K., Yunhao Fang, Zhao Qian, Zhen Sun \& Ai Wang 2020. Spatial planning for urban ventilation corridors by urban climatology, Ecosystem Health and Sustainability, 6:1, 1747946, DOI: 10.1080/20964129.2020.1747946

Il meteo 2020. Medie e totali mensili. https://www.ilmeteo.it/portale/medie-climatiche (Accessed March 2020).

ISTAT 2020. The Italian National Institute of Statistics-Popolazione residente al 1 gennaio, http://dati.istat.it/Index.aspx?DataSetCode=DCIS_POPRES1

Lai, C.-C., Shih, T.-P., Ko, W.-C., Tang, H.-J., Hsueh, P.-R., 2020. Severe acute respiratory syndrome coronavirus 2 (SARS-CoV-2) and coronavirus disease-2019 (COVID-19): the epidemic and the challenges. Int. J. Antimicrob. Agents 55, 105924

Legambiente (2019) Mal'aria 2019, il rapporto annuale sull'inquinamento atmosferico nelle città italiane. https:/ /www.legambiente.it/malaria-2019-il-rapporto-annuale-annuale-sullinquinamento-atmosferico-nelle-cittaitaliane/ (ACCESSED March 2020)

Ministero della Salute 2020. Covid-19 - $\quad$ Situazione in Italia. http://www.salute.gov.it/portale/nuovocoronavirus/dettaglioContenutiNuovoCoronavirus.jsp?lingua=italiano\&id $=5351 \&$ area $=$ nuovoCoronavirus\&menu $=$ vuoto $($ Accessed April 2020)

Morawska L, Cao J, 2020. Airborne transmission of SARS-CoV-2: The world should face the reality, Environ Int. Apr 10;139:105730. doi: 10.1016/j.envint.2020.105730.

Ogen Y., 2020. Assessing nitrogen dioxide $\left(\mathrm{NO}_{2}\right)$ levels as a contributing factor to coronavirus (COVID-19) fatality, Science of The Total Environment, Volume 726,2020,138605, https://doi.org/10.1016/j.scitotenv.2020.138605.

Sohrabi C., Alsafi, Z., O’Neill, N., Khan, M., Kerwan, A., Al-Jabir, A., et al., 2020. World health organization declares global emergency: a review of the 2019 novel coronavirus (COVID-19). Int. J. Surg. 76, 71-76.

Sterpetti A V, 2020. Lessons Learned During the COVID-19 Virus Pandemic, Journal of the American College of Surgeons, in press. DOI: 10.1016/j.jamcollsurg.2020.03.018

van Doremalen N., Bushmaker T., Morris D.H., Holbrook M.G., Gamble A., Williamson B.N., Tamin A., Harcourt J.L., Thornburg N.J., Gerber S.I., Lloyd-Smith J.O., de Wit E., Munster V.J. 2020.Aerosol and Surface Stability of SARS-CoV-2 as Compared with SARS-CoV-1. N Engl J Med. 2020 Apr 16;382(16):1564-1567. doi: 10.1056/NEJMc2004973. Epub 2020 Mar 17.

Wang Q., Su M., 2020. A preliminary assessment of the impact of COVID-19 on environment - A case study of China, Science of The Total Environment, Volume 728,2020,138915, https://doi.org/10.1016/i.scitotenv.2020.138915.

Wang Z., Zhu Y. 2020. Do energy technology innovations contribute to CO2 emissions abatement? A spatial perspective, Science of The Total Environment, Volume 726,2020,138574, https://doi.org/10.1016/j.scitotenv.2020.138574.

Wang, D., Hu, B., Hu, C., Zhu, F., Liu, X., Zhang, J., et al., 2020. Clinical characteristics of 138 hospitalized patients with 2019 novel coronavirus-infected pneumonia in Wuhan, China. JAMA 323, 1061-1069.

Zhu Y., Xie J., Huang F., Cao L., 2020. Association between short-term exposure to air pollution and COVID-19 infection: Evidence from China, Science of The Total Environment, Volume 727,2020,138704, https://doi.org/10.1016/j.scitotenv.2020.138704. 
Figures

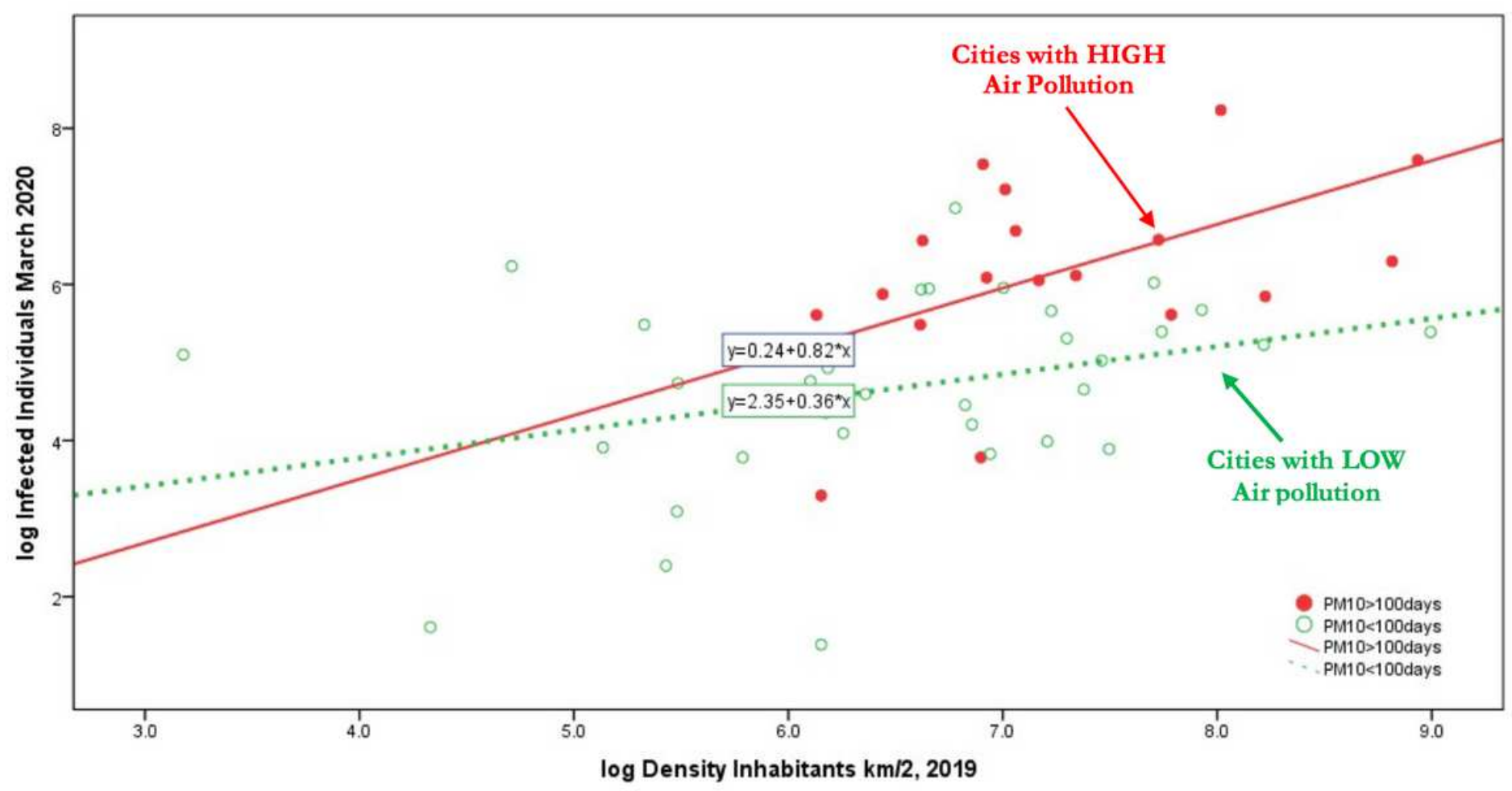

\section{Figure 1}

Regression line of Infected individuals on population density, considering cities with high or low Air pollution. 